John P. Kraljic

\title{
Yugoslav Communities in North America and the Tito-Stalin Split
}

World War II marked a watershed in the development of Yugoslav communities in North America. ${ }^{1}$ Croatian-Americans and Croatian-Canadians, by far the largest of the three major communities (Serbian and Slovenian being the other two), lived within the shadow of the Independent State of Croatia, which had declared war against, among others, the United States. However, their community's leadership, strongly influenced, alternatively, by Leftist, Communist or Liberal, pro-New Deal ideas, for the most part declared themselves in favor of the Partisans. The leadership of the Serbian community in North America generally favored the restoration of King Peter II and the Chetnik movement. Nevertheless, Serbs in the US and Canada also had very strong and vocal pro-Communist organizations. The Communist Party of Yugoslavia (CPY), which had relied on financial contributions of immigrants in the pre-War years, ${ }^{2}$ placed great store on the sympathy of Yugoslav immigrants and followed these developments with sustained interest. ${ }^{3}$

1 General histories of Croatian-Americans and Croatian-Canadians include Prpic, The Croatian Immigrants; Čizmić, Hrvati u životu; and Rasporich, For a Better Life. Serbian-Americans and Serbian-Canadians are discussed in Marković, Doseljenje Srba u Kanadu; Jončić, Iseljeništvo; and Skorić, Serbs in Ontario. General treatments concerning Yugoslav-Americans are found in Govorchin, Americans From Yugoslavia; and Prpic, South Slav Immigrants.

2 See, e.g., Tito's 20 October 1937 letter to Yugoslav communists in America in Tito, Sabrana djela 3:111-12. See also Dimitrijević, Odnos KPJ prema jugoslavenskoj, pp. 73-74.

3 As can be seen, for example, in a 20 December 1942 entry in Dedijer's diary: "Today we discovered that in America the well-known writer Louis Adamic strongly came out against Draža Mihailović, emphasizing that only the Partisans in Yugoslavia are leading the National Liberation War (...) Adamic's statement is of great importance." Dedijer, Dnernik, vol. 2, p. 36. See also a more thorough discussion of the importance placed in the work of emigrants in Ibid., vol. 3., pp. 173-84. The Partisan press also followed developments in emigrant communities. See, e.g., Buršić, Istarska partizanska štampa, vol. 1, p. 217 (citing to a 27 October 1944 issue of Hrvatski list); and Glas Splita, p. 111 (citing to a 5 July 1944 issue of the newspaper). A wide body of literature discusses Yugoslav-American communities in the United States and Canada during World War II. See, e.g., Čizmić, Prilog za istraživanje; Lees, Yugoslav-Americans; and Krišto, Brother's Keeper. 
A small but influential group of Communists in the Yugoslav communities in the US and Canada formed the bedrock of support for the Partisans and the post-War Federal People's Republic of Yugoslavia (FPRY). ${ }^{4}$ During most of the period prior to World War II, the membership of both the Communist Party of the United States (CPUSA) and the Communist Party of Canada (CPC) primarily consisted of immigrants. ${ }^{5}$ In order to work effectively among the larger immigrant groups which had a presence in the Parties, the CPUSA and CPC organized their foreign-born members into national sections or language groups.

In the CPUSA in the early and mid-1930s, the activities of Yugoslav immigrant members revolved around its Yugoslav Section. ${ }^{6}$ The Yugoslav Section had no independent existence or its own membership, being completely subservient to the Party. Its functions were limited to publishing newspapers, mostly in Croatian. The Party sought to extend its influence through other means, such as the establishment of Yugoslav Workers' Clubs which included non-Communists. The Communists assured their control over these Clubs through "fractions" which took unified positions on all issues of importance. ${ }^{7}$ The CPC organized its Yugoslav members somewhat differently, solely through Workers' Clubs, but these again remained tools of the Party. ${ }^{8}$

The Parties viewed the Clubs as "mass organizations," intended "to draw foreign born workers into the general stream of the (...) labour [and Communist] movement." Both Parties controlled a number of other "mass organizations," such as the International Worker's Order (IWO), a fraternal society established in 1930 by the CPUSA and divided into national groups, including a Croatian-Serbian one appearing in February 1935. ${ }^{10}$

During the second half of the 1930s, the Yugoslav groupings within the CPUSA and $\mathrm{CPC}$ went through organizational transformations as a result of the implementation of the "anti-Yugoslav" position of the Comintern. Yugoslav Communists in the North America initially resisted this position, viewing unitary Yugoslavism, "as [a] "higher and more revolutionary' starting point for the development of the workers' movement."11

4 Concerning pre-War Yugoslav Communist organizations in the United States and Canada, see generally Kraljic, The Croatian Section; and Granic, Establishing the South Slavic Radical Labour Press.

5 Only in 1936 did the CPUSA have more native-born than immigrant members. Ottanelli, The Communist Party of the United States, p. 128. In 1929, ninety-five percent of the CPC's membership consisted of Finnish, Ukrainian and Jewish immigrants. The percentage of immigrant members of the CPC remained high in the 1930s. Avakumovic, The Communist Party of Canada, p. 34 and p. 120.

6 The Yugoslav Section of the CPUSA was the second largest foreign language group in the Party in 1922-23 and the third largest in 1924-25. The members of the Section, with Croats no doubt constituting the overwhelming majority, numbered 1,290 out of 17,377 Party members in 1924. By comparison, in the same year the Jewish Section numbered 1,368 and the Finnish Section 7,099. Glazer, The Social Basis, p. 42.

7 Glazer, The Social Basis, p. 50.

8 Penner, Canadian Communism, p. 276.

9 Rodney, Soldiers of the International, p. 159.

10 Od četvrte do pete konvencije. Fraternal Outlook, June-July 1940, p. 51; and Walker, Pluralistic Fraternity.

11 Lojen, Uspomene, p. 161. 
In order to break this "deviation," the Comintern, through the CPY, sent a number of emissaries to implement structural reforms, reorganizing, for example, the Yugoslav Section into separate Croatian, Serbian and Slovenian Sections, each with its own newspapers, under the direction of a Mirko Marković. ${ }^{12}$

Yugoslavs formed an important component of the Communist Parties in the US and Canada, but they remained a vocal and well-organized minority within their respective communities and were dwarfed by such organizations as fraternal benefit societies. ${ }^{13}$ Of these, the Croatian Fraternal Union (CFU) was by far the largest and most important, with over 80,000 members in $1937 .{ }^{14}$

Though not a political body, the CFU remained subject to various political influences, with delegates to its conventions arrayed in blocs fighting to gain control of the organization. In this regard, Croatian Communists in North America were no exception, working within the CFU as leaders of groups variously labeled as the "Progressive Bloc" or "Left Wingers." ${ }^{15}$ But prior to World War II, the Communists and their sympathizers were thwarted in their bid to take control of the CFU, though they succeeded in placing their followers in leading positions of various lodges.

World War II marked a turn-around in the fortunes of Yugoslav Communists in the US and Canada. The occupation and dismemberment of Yugoslavia, the invasion of the Soviet Union and the entry of the US into the war fortuitously occurred within the course of approximately eight months. The Communists used their organizational skills, as well as the increasing sympathy of Yugoslav-Americans toward the USSR and the Partisans, to establish a leading position, primarily in the Croat community. ${ }^{16}$ Their

12 Marković's work on this reorganization is generally discussed in Kraljic, The Croatian Section, pp. 145-49.

13 A report from the late 1930s estimated that there were 1,800 to 2,000 Croatian-American members of the CPUSA, an estimated 500 whom lived in western Pennsylvania, 200 in California and on the West Coast, and 100 in New York. Tamiment Institute, New York University, Earl Browder Papers, Series II, Subject Files, microfilm reel 4, no. 65, R-2467. An indication of sympathizers of the Party may be gathered from certain statistics of some of the "mass organizations." In 1933, thirty-eight Yugoslav Workers' Clubs claimed 1,718 members and in 1934 sixty Clubs claimed approximately 3,000 members. Prva konferencija J.R. kluba u USA. Borba, 1 March 1933, p. 5; and Čizmić, Hrvati u životu, p. 241. In 1940, the IWO's Croatian Section claimed 8,000 adult and children members. Od četvrte do pete konvencije. Fraternal Outlook, June-July 1940, p. 51. In Canada, one author estimates that Croats constituted ten percent of the CPC's 16,000 members in the late 1930s. Avakumovic, The Communist Party of Canada, p. 121.

14 Mladineo, Narodni adresar, p. xxxii. The most comprehensive work on the CFU is Čizmić, Povijest Hrvatske bratkse zajednice. See also Smoljan, Sto godina Hrvatske bratske zajednice.

15 An unsympathetic pamphlet summarizing the history of Communist-influence in the CFU is Suljak, The Communist Conspiracy.

16 In what proved to be a future embarrassment, the Yugoslav Communists initially supported the Chetnik movement, with Mirko Marković later having to live down the fact that he met with King Peter II during the latter's visit to the United States in 1942 where Marković presented a check to the King for \$1,000, as noted in the memoirs of the pro-Chetnik Yugoslav ambassador to the United States. Fotich, The War We Lost, p. 184. See also Dedijer, Dnevnik, vol. 3, p. 56. A collection of Marković's articles which appeared in the United States during World War II is found in his Borba u Americi. Memoirs of note concerning the work of Yugoslav Communists during the War include Lojen, Uspomene; Prica, Amerika; and Dedijer, Stevan Dedijer. 
influence may be gauged by the fact that the Croatian-American Party newspaper, $\mathrm{Na}$ rodni glasnik, became a daily which boasted a circulation of $15,000 .{ }^{17}$

Croatian Party members played an especially important role in the American Slav Congress, established by the Communists in 1942 as "to influence American government policy toward resistance movements and governments in Eastern Europe." ${ }^{18}$ Communists also strongly supported the establishment of the Congress of American Croats which had been "decisive in directing the political sympathies of Croatians in the US in favor of Tito and the Partisans." ${ }^{19}$ Meanwhile, in Canada, the Communists established a new umbrella organization, the Council Canadian South Slavs, in June 1944. ${ }^{20}$

Their work during the War and the continued euphoria which many members of the Yugoslav-American community felt towards Tito, the Partisans and the "New" Yugoslavia fed into the Communists' ultimate success - the takeover of the CFU's leadership by their allies at its 1947 Convention. ${ }^{21}$ This represented the pinnacle of Communist success in the Croatian-American community. From this height, the Communists suffered a rapid decrease in their influence, chiefly for three reasons. First, the late 1940s saw the rise of the anti-Communist McCarthyist crusade in the US, with an echo of same in Canada. Second, the arrival of refugees displaced by the fall of Royalist Yugoslavia and the Independent State of Croatia and the defeat of the Chetniks changed the composition of immigrants who were politically active in Homeland affairs from a predominately leftist to a more starkly rightist strand. Third, the Tito-Stalin split caused an irremediable decline in far left influence in Yugoslav-American communities.

The split initially caused incredible confusion among Party members in the US and Canada as can be seen in their newspapers, such as Jedinstvo. Established in June 1948, the paper resulted from the merger of the former Croatian-, Serbian- and Slovene-language Party newspapers in Canada. ${ }^{22}$ Jedinstvo first took a cautious approach, referring to the leadership of the CPY as "comrades." The paper republished the texts of both the Cominform resolutions as well as the replies of the CPY leadership. ${ }^{23}$ The first page of Jedinstro's 23 July 1948 edition, for example, carried an article by Moše Pijade. ${ }^{24}$

17 Andrija Josipović, Uspomene na Stjepana Lojena. Narodni glasnik, 31 January 1968, p. 6.This figure needs to be viewed cautiously as possibly being inflated.

18 Isserman, Which Side Were You On?, p. 111.

19 Čizmić, Hrvati u životu, p. 336. The Congress held its first convention in Chicago in February 1943 in the presence of 927 delegates. Ibid.

20 Skorić Serbs in Ontario, p. 32.

21 Šljak, The Communist Conspiracy, pp. 16-23.

22 Neka živi naš demokratski list Jedinstvo! Jedinstvo, 15 June 1948, p. 1. The author has been unable to locate in the United States or Canada any issues of Narodni glasnik for the period studied in this paper. Tragically, it appears that the only complete set is found in the Institut za migracije i narodnosti in Zagreb, though the author has been advised that, unfortunately, much of the Institut's holdings of the paper are in a parlous state.

23 See, e.g., Izjava Centralnog komiteta Kom. Partije Jugoslavije pobudom Rezolucije Inform. Biroa. Jedinstvo, 9 July 1948, p.1; and Odluka CK KPJ o isključenje Hebranga i Žujovića iz KPJ. Jedinstvo, 13 July 1948, p. 1.

24 Besprincipijelnost kao oružje u borbi za 'principe.' Jedinstvo, 23 July 1948, p. 1. 
Party members retained hope for a healing of the rift, as shown by a 6 August 1948 Jedinstvo editorial. Noting that "Canadian Yugoslavs had been proud and continue to be proud of the heroic achievements of the National Liberation Army of Yugoslavia and of the Yugoslav peoples," the editorial emphasized that Yugoslav-Canadians followed with great interest events in their homeland, including the recent "disagreements" with the Soviet Union. The paper had hoped that the CPY's Fifth Congress would have resolved the issues, but it now appeared that nothing had been accomplished. "We are most troubled by the question: can Yugoslavia build a new democracy, can it build socialism, without the support and cooperation of the New Democracies, and especially of the Soviet Union? (...) We raise our voices, and join in all other voices which call for the complete resolution of all these substantive issues of the international workers' movement (...)" Nevertheless, Jedinstvo emphasized that it could only see Yugoslavia remaining independent as an "active partner with the New Democracies and the Soviet Union."25

The openness displayed by the Communist press began to dissipate during the following two months. No longer did the newspapers honor CPY leaders with the moniker of comrades. Now the heads of the Yugoslav Party were labelled as Titova grupa, Tito's clique. ${ }^{26}$

This period also saw the resignation of a number of Yugoslav diplomats from their posts in the US and Canada, including several who had been prior members of the CPUSA and CPC. One was Tomo Babin. Babin served as a volunteer with the International Brigades in Spain and played a key role in the establishment of the Yugoslav Seaman's Club in New York, a Communist-controlled organization of Yugoslav seamen and dockworkers. ${ }^{27}$ Documents made available after the Cold War indicate that Babin played a more nefarious role, routinely providing information concerning shipping activities in New York harbor to the Soviets. ${ }^{28}$ His reward came after the War when he became an attaché to the Yugoslav embassy in Washington. After the Tito-Stalin split, Babin ironically, sought political asylum in the US. ${ }^{29}$

A similar situation occurred in Canada. There, Pavle Lukin, a counselor in the Yugoslav Embassy, resigned on 30 September 1948, noting in his resignation letter that he "believes the policies of the current Yugoslav government to be treasonous to the fundamental interests of our country (...) When the criticisms against the policies of the

25 Želimo brzo i pravednorešenje spornih pitanja. Jedinstvo, 6 August 1948, pp.1-2. Similar sentiments about Yugoslavia's inability to go it alone is found in, e.g., Nova Jugoslavija ne može bez tiješne suradnje sa SSSR-om i novim demokracijama. Jedinstvo, 10 September 1948, p. 1.

26 See, e.g., Kuda vodi nacionalizam Titove grupe u Jugoslaviji (iz Moskovske Pravde). Jedinstvo, 8 October 1948, p.1.

27 Concerning the work of the Seamen's Club, see Maštruko, Na svim meridijanima.

28 Haynes \& Klehr, Venona, p. 181.

29 Borba za obranu i oslobodjenje Babina. Jedinstvo, 22 July 1949, p. 3; Tomo Babin. Jedinstvo, 6 April 1956, p. 1. See also Vojtěchovsky, Iz Praga protiv Tita!, p. 119. Babin died in Poland in 1956. Tomo Babin. Jedinstvo, 6 April 1956, p. 1 . 
current government in Yugoslavia were first published, I rejected those critiques. However, in studying these critiques, together with the events which have taken place over the course of the past three months, I have concluded that the criticisms are completely correct and were unquestionably necessary (...) Our country cannot progress toward socialism without close brotherly cooperation with the Soviet Union and the countries of the New Democracies (...)"30 Lukin's resignation accompanied those of a number of other employees of the Embassy who had previously been active in the Yugoslav community in Canada, including Stjepan Miošić and Vojin Grbić. ${ }^{31}$

This period also saw the beginning of "differentiations" within Party ranks. On October 22, 1948, for instance, Jovan Djajić, one of the Serbian-language editors of Jedinstvo, was dismissed from his post. Born in Bosnia \& Herzegovina, Djajić joined the CPC in 1933 and served as a commissar in the Spanish Civil War. He returned to Canada following the War and became a member of the Council of Canadian South Slavs, a Communist dominated umbrella group. ${ }^{32}$ Disingenuously, Jedinstvo initially claimed Djajić voluntarily sought to resign from his post as a result of "his desire to go to Yugoslavia (...) in November." ${ }^{33}$ However, the resolutions of the Executive Committee of the Council of Canadian South Slavs, adopted at its biannual meeting on 11-12 December 1948, set forth the true reasons for Djajićs expulsion, noting that he had "come out in favor of the policies of the Tito leadership of the CPY and because he is committed to carrying out a struggle [in favor of same] within [our] organization (...)"34

Jedinstvo's pages were filled with charges and countercharges made by the respective supporters of Tito and Stalin, usually set forth in various "open letters." Those supportive of Tito generally came from former CPC and CPUSA members who had returned to Yugoslavia after World War II. These returnees had been encouraged to settle in

30 Pavle Lukin i šestorica drugih uposlenika kod poslanstva FNRJ u Ottawi položili ostavku. Jedinstvo, 5 October 1948, p. 1.

31 Miošić had been a member of the Inner Board or Executive Council of the WPEC. Izvještaj sa četvrte konvencije. Borba, 6 August 1935, p. 3.

32 National Archives of Canada, Ottawa, Rossiiskii tsentr khraneniia i izucheniia dokumentov noveishei istorii, fond 545, opis 6, delo 546, no. 60, microfilm reel K-262; Anti-tenkovska baterija Petka Miletića. Slobodna misao, 20 July 1937, p. 2; and Božo Prpić, Umro Jovan Djajić. Matica, January 1975, p. 29.

33 Drug Jovan Djajić razrješen dužnosti. Jedinstvo, 22 October 1948, p. 1.

34 Rezolucija Gavnog Odbora Vijeća Kan. Južnih Slavena. Jedinstvo, 14 December 1948, p. 1. Djajić’s resignation from his posts is further discussed in 20 godina: Kratki pregled, pp. 88-90. Djajić published a brochure in Canada setting forth his view in April 1949 called Neopravdana borba protiv Jugoslavije. See also Gdje su sada. Jedinstvo, 30 November 1950, p. 6. At the same meeting, the Council also called for a halt to providing further financial assistance to the FPRY which had been collected within a "General Fund. "The proceeds of the Fund were to be used to purchase machinery and equipment. Andrija Dražić, one of 5 members of an audit committee which reviewed the books of the Fund in June 1948, notes that many of the contributions had been provided as loans by those planning to return to Yugoslavia; the certificates issued to them would then be paid out in Dinars in Yugoslavia. Supposedly, the FPRY ultimately paid all claims represented by the certificates, avoiding a legal clash with the Council. Andrija Dražić, Certifikati Rekonstrukcionog Fonda u Kanadi. Novi list, 26 August 1952, p. 1. See also Rasporich, For a Better Life, pp. 176-78. 
the "New" Yugoslavia after the War by both Yugoslav authorities and the immigrant Communist press as part of the so-called Radnik movement. Thousands of pro-Titoist, or perhaps merely patriotic or home-sick, Yugoslavs re-emigrated back to Yugoslavia in the immediate years following the War, many being transported by the Yugoslav ship Radnik. Communist newspapers in the US and Canada documented almost every sailing of the ship loaded with immigrants. Ironically, a large number of them left Montreal in mid-June 1948, a group which included Edo Jardas. ${ }^{35}$ This group included Edo Jardas, one of the top Croatian-Canadian Party leaders.

Jardas stands apart from many CPC and CPUSA Party members in that he had a professional career, working as a government official in Yugoslavia from 1919 to 1926, during which he became a member of the Orjuna, a right-wing group which propagated Yugoslav unity. Jardas' subsequent entry into the $\mathrm{CPC}$ raised disbelief among his family and friends, one of his Orjuna colleagues arguing that the rumors of Jardas' conversion to Communism must have been a pure "provocation." ${ }^{36}$ After serving in the International Brigades in Spain where he sustained serious wounds, Jardas returned to Canada, subsequently becoming a member of the CPC's Central Committee. ${ }^{37}$

The Cominform resolution appeared as the Radnik slowly made its way across the Atlantic. Subsequent reports claimed that the passengers "all" came out in favor of Tito. Such an assertion is belied by the facts, as we will shortly discuss. Jardas attended the Fifth CPY Congress (subsequently becoming a long-serving CPY and Yugoslav government official). Jardas initially attempted to convince his former comrades in Canada of the righteousness of the Yugoslav Party's position. To no avail. In an "open letter" to Jardas, a leading group of Yugoslav Canadian Communists accused Jardas of taking an "incorrect path," noting that they wanted to "assist him" in coming back to the Party fold. "To the extent that you continue to go on [your current] path, know that in us you will have enemies and that we will act towards you as we have acted against the entire Tito clique and their incorrect policies." 38

Jedinstvo did not limit its critiques to Jardas. A multipart series subsequently responded in detail to various letters sent by other returnees to Yugoslavia. The paper

35 Povratnici prve grupe na putu za Jugoslaviju. Jedinstvo, 29 June 1948, p. 1.

36 Državni arhiv u Rijeci, Edo Jardas, box 1, folder 1.4. See also a letter from Jardas' sister found in ibid.; and Edo Jardas, Otvoreno pismo Stankoviću i ostalim režimskim špionima od bivšeg orjunaša. Borba, 12 October 1932, p. 3.

37 Državni arhiv u Rijeci, Edo Jardas, box 2, folder 2.1. See also National Archives of Canada, Ottawa, Rossiiskii tsentr khraneniia i izucheniia dokumentov noveishei istorii fond 545, opis 6 , delo 564 , no. 30, microfilm reel K-263 (Jardas' repatriation recommended due to his wounds and because of the request "of his national organization in Canada to carry on organization and newspaper work").

38 Otvoreno pismo druga Jardasa. Jedinstvo, 19 October 1948, p. 2. That time cured this animosity to some extent is reflected in the correspondence Jardas later had with one of the signatories of the "open letter," Marijan Kružić. Interestingly, despite his close association with the CPC, Kružić apparently was not an "official" member of the Party. Državni arhiv u Rijeci, Edo Jardas, box 1, folder 4.2. 
published a number of these letters (though it is not clear whether same were edited), including, among others, one from a group of returnees in Rijeka questioned the paper's report of the death of Arso Jovanović, a letter from Anton Drašner, ${ }^{39}$ asking that the paper and leadership in Canada not support the spread of "lies" about the CPY, two letters from Ivan Lindarić, ${ }^{40}$ and a letter from a group of returnees in Gospić. ${ }^{41}$

Not all returnees though came out in Tito's favor. Probably the most important of the returnees who became a Cominformist was Mirko Marković. Marković joined the CPY in 1924 and later moved to the USSR. He became the leading Yugoslav-American Communist after arriving in the US in 1935, even serving as commander of an American-dominated battalion in Spain, in spite of having lived in the US for only a few of years. After returning to Yugoslavia in 1945, he became the foreign political editor of Tanjug and a dean at Belgrade. Yugoslav authorities arrested him in 1949 and he spent the next 5 years on Goli Otok. ${ }^{42}$

A review of the Communist Party-dominated press during and after 1948 indicates that a majority of the Yugoslav members of the CPUSA and CPC retained their loyalty to Moscow. This is reflected in the memoirs of Steve Nelson, a Croatian-American born Stjepan Mesaroš, who rose to become one of the top leaders in the CPUSA. ${ }^{43}$ Nelson claims that he had been tasked to explain the Party's position to Yugoslav members in New York. "At a decisive meeting, I strongly condemned Tito, and of the hundreds of Party members present, only two dared to vote against the position I presented. We didn't have all the details then, but I can see now that many would not have listened to

39 Drašner, born in Daruvar, had been a volunteer in the International Brigades in Spain. He died in 1961 and is buried in Opatija. See, e.g., Štimac, Erdeljac, Lindarić, Serdar, Drašner - ranjeni. Slobodna misao, 25 September 1937, p. 1.

40 Lindarić, a native of Krk Island, had also been a volunteer in the International Brigades in Spain. See Pavlić, Lindaric, Ivan, pp. 194-98.

41 Razgovor s drugovima u Jugoslaviji. Jedinstvo, 5 November 1948, p. 3, 12 November 1948, p. 3, and 19 November 1948, pp. 2-3.

42 Despite his importance both in the early history of the CPY as well as his work among Yugoslav-Americans in the United States, Marković was virtually ignored in Communist historiography in Yugoslavia. For instance, the memoirs of Stjepan Lojen, the leading Croatian American Communist in the late 1930s and during World War II, make no mention of him. See generally, Lojen, Uspomene. Marković published a number of articles in Naše novine, the successor newspaper to Jedinstvo in Toronto, in the second half of the 1980s which those researching this most interesting figure should consult further. See, e.g., Mirko Marković, Kune se u Titu i poriču ga istodobno. Naše novine, 16 January 1986, p. 6; Miomir Marić, Prvi kauboj u Beogradu. Naše novine, 12 June 1986, pp. 6-7; and Miomir Marić, Povratak sa kamenog ostrva. Naše novine, 26 June 1986, pp. 6-7. After his release from Goli otok, Marković married another former inmate, and continued to suffer harassment from Yugoslav authorities thereafter. Miomir Marić, Povratak sa kamenog ostrva. Naše novine, 26 June 1986, pp. 6-7.

43 Nelson (1903-1993) arrived in the United States in 1922 and joined the CPUSA in 1925. He attended the International Lenin School, thereafter undertaking Comintern missions to China and India. During the Spanish Civil War he served as commissar of the Lincoln and the Lincoln-Washington Battalions and afterwards became a member of the Central Committee of the CPUSA. He was convicted in 1950 for attempting to overthrow the United States government, which was overturned by a 1956 United States Supreme Court decision. Though breaking with the Party in 1957, Nelson served as the longtime head of the Veterans of the Abraham Lincoln Brigade. See generally Nelson, Barett \& Ruck, Steve Nelson; and Eric Pace, Steve Nelson, Ex-Communist Tied To Ruling on Sedition, Dies at 90. The New York Times, 14 December 1993, p. B8. 
Tito's side even if we had. I lapsed into the classical description of the Soviets as the leading party, a stance that still had currency $(. .).[\mathrm{We}]$ readily agreed that anyone who parted with the Soviet Union was a renegade." ${ }^{\prime 4}$

Those who had left or been expelled from the Party on account of their pro-Titoist sentiments focused their efforts on establishing new organizations and newspapers. Aleksander Jurich headed this work. Jurich had been one of the three "owners" of $\mathrm{Na}$ rodni glasnik in December, 1940, an amateurish attempt to "cover-up" its continued connection with the Party. ${ }^{45}$ Jurich initially joined the Socialist Party after coming to the US in 1910, later joining the CPUSA. ${ }^{46}$ Jurich owned the Starlight and New Starlight restaurants in New York, both of which he advertised in the Communist press. ${ }^{47}$

In early 1949, Jedinstvo claimed that Jurich was looking to take over the New York-based newspaper Hrvatski svijet. ${ }^{48}$ Hrvatski svijet had been previously published by Don Niko Gršković. A former Catholic priest, Gršković became a member of the London-based Yugoslav Committee during World War I. ${ }^{49}$ Following that War, Gršković's paper (titled at various times as Svijet and Jugoslavenski svijet), expressed a generally Pan-Slavic, pro-Soviet, pro-Yugoslav, but also a pro-Croat and anti-monarchist point of view. ${ }^{50}$ Not surprisingly, during World War II, by which point the paper came under the stewardship of Anton Tanasković, it took up Tito's cause. The Tito-Stalin split did not lessen the paper's Russophile, Slavistic tendencies, but it nevertheless came out four-square in Tito's favor.

Its viewpoint was most succinctly expressed in a 6 July 1948 editorial which argued that "the overwhelming majority of people here have expressed themselves in favor of Tito. Against Tito are the extreme Communists and the right-wingers. The more moderate among our people, who are first Croats, Yugoslavs and Slavs, approve of Tito and condemn the interference of the Cominform in Yugoslavia's business. ${ }^{{ }^{51} \mathrm{~A}}$ subsequent response to the editorial noted that it set forth the thoughts of "all American Croats-Yugoslavs who have always been in favor of the freedom, democracy and independence of

44 Nelson, Steve Nelson, p. 290.

45 Kuda vodite H.B. Zajednice. Nezavisna Država Hrvatska, 22 March 1941, p. 3.

46 Concerning Jurich (1892-1979), see Smoljan, Tito i Iseljenici, p. 324.

47 Advertisements for Jurich's New York restaurant in 1934 in the CPUSA's Daily Worker described it as a place "Where Comrades Meet." Conveniently, the restaurant's location on $15^{\text {th }}$ Street between Union Square and Irving Place, and later on Irving Place, placed them only several blocks from CPUSA headquarters.

48 Rad Titovih agenata u SAD. Jedinstvo, 6 May 1949, p. 2.

49 Concerning Gršković’s work during World War I, see Čizmić, Jugoslavenski iseljenički pokret. See also Hranilović, Novinarski djelatnost, pp. 49-64.

50 This did not mean, however, that Communists looked on Gršković and his newspaper with sympathy. See, for example, Stjepan Lojen's brutal critique in his Loyen, Tko gradi, p. 13. For his part, Gršković noted Croatian Communists had, after accepting the CPY's and Comintern's anti-Yugoslav line, become "overnight greater Croats than all dead and living Croats," concluding that they exploited the Croatian name merely to advance their own purposes. U svjetlu istinu. Svijet, 23 January 1938, p. 2; and Tko je za jedinstvo hrvatskog naroda. Svijet, 29 September 1936, p. 2.

51 U današnjem sporu, naš narod je za Tita. Hrvatski svijet, 16 July 1948, p. 2. 
the Croatian and Yugoslav peoples. ${ }^{52}$ The paper later carried the full text of Tito's report to the CPY's Fifth Congress in multiple installments ${ }^{53}$ and stories from Yugoslavia in an attempt to show that Tito had wide support in the country. ${ }^{54}$

The paper did not hide its contempt for the hypocrisy of Stalin's supporters within the community noting that while "Tito is no longer good (ne valja)," he had been "until recently the best. Nevertheless, most people are not paying attention to the advice of 'comrades,' as our people first stand in favor of Slavdom (Slavenstvo) and Slavic solidarity, for whom the 'comrades' do not care, but only use them if they are of use to them." 55

Despite Hrvatski svijet's affinity for Tito, Jurich and a group of supporters struck out on their own, establishing the Novi list corporation in 1948 which subsequently published a paper under the same name in New York starting in $1949 .{ }^{56}$ Novi list often included vitriolic pieces which attacked the Stalinists. One editorial, for example, noted that the Cominformists around Jedinstvo and Narodni glasnik engaged in multiple forms of treason, being traitorous to the progressive movement as well as to their own people." ${ }^{57}$

Pro-Titoists further established various Yugoslav-American Clubs, a number taking the title "Friends of New Yugoslavia." The organizers of one such club in Chicago, declared that it would seek to "counter the Cominform's destructive influence of extremist Communist elements among our people in America." ${ }^{\text {8 }}$

Pro-Titoist elements also found a voice in Louis Adamic. The Slovene-born Adamic became the most prominent Yugoslav-American intellectual in the later 1930s and during the 1940s, having established himself as a prominent writer and political and social commentator. A supporter of the New Deal and a promoter of America's cultural and ethnic pluralism, Adamic retained his interest in Yugoslavia becoming, during World War the II, the President of the pro-Titoist United Committee of South-Slavic Americans. ${ }^{59}$ His 1943 work, My Native Land, argued forcefully in favor of the Partisans,

52 Marko Jelavić, Za naš narod u Starom kraju ne treba biti u bojaznosti. Hrvatski svijet, 30 July 1948, p. 2.

53 See, e.g., Iz izvještaja Maršala Tita V kongresu Komunističke stranke Jugoslavije. Hrvatski svijet, 31 August 1948, p. 2.

54 See, e.g., Povodom kampanje Internacionalnog komunizam protiv Jugoslavije. Hrvatski svijet, 1 October 1948, p. 2 .

55 Jugoslavija i naši 'drugovi’ u Americi. Hrvatski svijet, 15 October 1948, p. 2.

56 Will Lisser, Yugoslavs in U.S. Face Party Fight. The New York Times, 11 February 1950, p. 4. Novi list claimed a circulation of 3,400 in 1952. Statement of Ownership, Management and Circulation. Novi list, 7 October 1952, p. 4.

57 Izdaje ih njihov vlastiti rad. Novi list, 6 May 1952, p. 2.

58 Zabava prijatela Nove Jugoslavije. Hrvatski svijet, 21 March 1950, p. 2.

59 The United Committee included on its board both Communists and non-Communists, chief among the former being Mirko Marković who allegedly had an important influence on Adamic, which other leaders of the Committee noted. Maletić, Ujedinjeni odbor, p. 100. The Committee published its own Bulletin (edited by Adamic) which Maletić states had a circulation of up to 25,000 and published numerous pamphlets and brochures supportive of Tito. Maletić states that the Committee received tremendous assistance in mailing and distributing its Bulletin from the New York based Yugoslav Seamen’s Club. Ibid. 
exposing the Chetniks as collaborators and condemning the pro-Chetnik and anti-Croat work of Konstantin Fotić, the head of the Yugoslav Legation in Washington. ${ }^{60}$

Like Hrvatski svijet, Adamic publicly supported Tito after the Cominform split. Writing in October 1949, Adamic claimed that "The New Yugoslavia is a terrific place. The people are caught up in a strenuous effort linked to a key sense of the future (...) The Yugoslav position is morally and politically sound. The vast majority of citizens know the truth of what is going on in Yugoslavia and they are for the basic policies of Tito's government, for the new system." ${ }^{1}$ Adamic's pro-Titoist English writing found expression in a new journal he published, Trends and Tides, and in his last book, The Eagle and the Roots, which chronicled the six months he spent in Yugoslavia in $1949 .{ }^{62}$

Yugoslavia placed much store in garnering support for their policies against Stalin among Yugoslav immigrants. While we have not as of yet been able to determine what if any financial support had been provided by FPRY in this regard, clearly the Communist government provided moral encouragement by such tactics as having officials make frequent appearances at community events.

These efforts should be seen as part of the wider effort undertaken by Yugoslav authorities to develop "soft power." ${ }^{63}$ Yugoslavia sought to influence world public opinion through a variety of methods, such as promoting Yugoslav culture (examples include the English language glossy magazine Yugoslavia and the 1950 exhibition of medieval Yugoslav art organized by Miroslav Krleža).

In the struggle with the Comintern, Yugoslavia proved adept at making its positions known and palatable to Western tastes, beginning with the publication of its White Book, ${ }^{64}$ and using the writings of such authors as Vladimir Dedijer as well as Adamic and various American and British writers.

Yugoslav immigrants were useful in this regard as they were a potential pressure group which could be used to steer American and Canadian foreign policies in favor of Tito. Moreover, the support expressed for Tito had the added benefit of legitimizing the regime, as can be deduced by the coverage provided in newspapers in Yugoslavia concerning its emigrant communities. Such communities were also seen as a potential source of economic support for the war-ravaged (and boycotted) country.

With the active support of the Yugoslav government, one can say that the pro-Titoists "won" the battle with the Cominformists in the immigrant communities (though

60 Adamic, My Native Land. Bogdan Novak has argued that Adamic turned to Tito "because of his ideological closeness to Tito and the Communist cause. Adamic was convinced that in the final stage Tito's Communism would bring a better life to the great majority of the common people." Novak, Why Adamic Shifted, p. 190.

61 Louis Adamic on New Jugoslavia. Hrvatski svijet, 6 October 1949, p. 2.

62 Adamic, The Eagle and the Roots. Many have sought to paint his subsequent mysterious suicide as actually having been a cover for a murder committed by his political enemies, whether pro-Chetniks or pro-Cominfomists. Bogdan Radica, for instance, claimed that Adamic "was the victim of Chetniks, who could not forgive him for the truth that he had written about them and Greater Serbianism." Radica, Mi u Americi, p. 99.

63 "Soft power" was a term developed in the 1980s. See generally Nye, Soft Power.

64 Ministry of Foreign Affairs, White Book. 
not among Party members). The Stalinists, on the other hand, though having (at least the moral) support of the USSR and its allies, could not hope for any overt diplomatic or other institutional assistance. The issues within the relatively small Yugoslav immigrant communities could not be seen as one of vital importance to the Cominform. Perhaps more importantly, the Cominformists were clearly on the "wrong side" in the then opening years of the Cold War. With the Soviet Union taking on the role as the primary foe of the US and its allies, any group favorable to the Cominform simply could not garner much support among individuals looking to make a better life for themselves in the post-war, economically booming societies of North America. As was one group in Chicago wrote in 1950, "we are first and foremost Americans and we are ready to defend America without regard to political questions. To us, America comes first, we live in it freely and live better than we would anywhere else in the world, which is the reason we remain in America. If we did not believe this, we would have returned to Europe long ago."65

However, despite these sentiments, the "victory" of Titoist forces in the propaganda war within Yugoslav-American communities represented a rather hollow one. Evidence suggests that the activity of members of numerous organizations suffered a steep decline in the 1950s. No doubt the internecine strife among former comrades caused many "non-activists" to choose to no longer participate in groups which had for the most part been initially established as social and cultural, and not political, organizations. An example of this can be seen in the Yugoslav American Home in New York City. Established in 1948 on Manhattan's West Side, the Home's shareholders included hundreds of individuals, as well as organizations, many of which clearly had connections with the CPUSA. ${ }^{66}$ The Tito-Stalin split lead to a vicious battle for control over the Home, which no doubt led many "ordinary" members to ultimately determine not to be part of the organization at all. ${ }^{67}$

65 Zabava prijatela Nove Jugoslavije. Hrvatski svijet, 21 March 1950, p. 2.

66 Ujčić, A Journal Commemorating. An original version of this souvenir book is found in the New York Public Library.

67 See, e.g., Club in Row Over Reds; Yugoslav-American Home Heads Deny Control by Communists. New York Times, 13 January 1951, p. 10. John Blasko noted that the "poor attendance at affairs held in the Yugoslav-American Home" had likely been caused by its placement on "the subversive list as a front for the American Communist Party - accepting dictates from the Cominform to destroy Democracy.” John Blasko, America Yugoslav Homes. Novi list, 28 February 1952, p. 4. The building which housed the Home no longer exists, its site having been taken over by the Bus Terminal of the Port Authority of New York and New Jersey. Carol Fijan Starobin, whose father had been active in pro-CPUSA circles in the Croatian community in New York, advised the author that the organ in the Home was donated to the Community Baptist Church in Bayside, New York.Carol Fijan Starobin, interview by author, Great Neck, New York, 26 March 1999. It appears that after the Home had been demolished, its funds were taken over by the Yugoslav Seaman's Club, which had been included among organizations deemed to be subversive by the U.S. Department of Justice. See Zinn, Postwar America, p. 157. The Club was renamed the New York City Seamen's Club in 1998; though the entity still legally exists, it appears to have no further functions, its last act known to this author being the donation of its remaining monies to the $\mathrm{CFU}$ for scholarship purposes (under the name New York City Seamen's Club Fund). See https://croatianfraternalunion. org/fraternal-programs/scholarship. 
These issues were clearly exacerbated by $\mathrm{McC}$ arthyist policies adopted by governments in both the US and Canada, policies which were joined with non-official anti-foreign and specifically anti-Slavic campaigns within both countries. Such trends further caused many older immigrants and their children and grandchildren to drift away from participating in ethnic organizations.

Internal fractures within the communities only grew with the influx of large numbers of mainly nationalist, anti-Communist refugees to Canada and the US from Yugoslavia. These new immigrants established a plethora of new organizations which overtook the older, pro-Communist organizations (of both the Stalinist and Titoist variety) in size and influence. Already by 1955 the Titoist Novi list had folded, while the Friends of New Yugoslavia Clubs never grew into a national organization.

As for the Stalinist organizations, their newspapers surprisingly, though no longer having any mass support, eked out an existence for decades. Despite the rapprochement between the Soviet Union and Yugoslavia in the mid-1950s, their newspapers engaged in continuing arguments with former comrades who had chosen Tito over Stalin. Mirko Marković, for example, published in the 1980s many articles in Naše novine, the successor to Jedinstvo, ${ }^{68}$ critical of "official" Yugoslav historiography which generally ignored his role in the Communist movement in the US. ${ }^{69}$

Another historical dispute in Naše novine revolved around Edo Jardas. An interview given to the Zagreb-daily Vjesnik in 1973 spoke about Jardas' role in the history of the Communist movement among Yugoslav immigrants in Canada. ${ }^{70}$ Jardas' description raised the ire of many in Canada who viewed him as unfairly taking the credit for the work of others in the movement. An announcement appeared in Naše novine on 28 November 1973 which severely criticized Jardas. Jardas not only disputed the criticisms but questioned the sincerity of those who issued the announcement, asking why such an attack had been raised "against a person who had spent his entire life toiling in the class struggle for the emancipation of the working class?" ${ }^{11}$

68 According to Anton Kostelac, the name Jedinstvo had been dropped because some had thought that the name would be associated with Titoist slogan "Brotherhood and Unity" (Bratstvo i jedinstvo) and that the new name would attract new readers. Kostelac noted that at least one supporter of the newspaper claimed that the change "would fool no one - and he was right." Undated correspondence received in May 2004 from Anton Kostelac to the author. Skorić, Serbs in Ontario, p. 42, implies that the new name arose in an attempt to heal the rift between the former Stalinists and a Titoist group called Bratstvo i jedinstvo.

69 See, e.g., Mirko Marković, Kako Dedijer 'priča istoriju.' Naše novine, April 14, 1982, p. 3. The existence of Naše novine allowed persons such as Marković, who remained under proscription in Yugoslavia until his death, to publish a portion of his memoirs in a series of articles and also provided a forum to discuss the prison camp at Goli Otok.

70 The interview appeared in September 1973 and has been published as part of collection of interviews. Stuparić, Revolucionari, pp. 88-100. As noted by one of his former comrades: "Jardas is well known to all of us who worked with him or cooperated with him in our movement. We all know that Comrade Jardas is a terribly and insanely ambitious man." Pismo Petra Erdeljaca iz Zagreba. Naše novine, 20 February 1974, p. 4.

71 Državni arhiv u Rijeci, Edo Jardas, box 1, folder 4.2 (14 January 1974 letter from Edo Jardas to the Executive Committee of the Alliance of Yugoslav Canadians). The controversy centered on, among other things, Jardas' diminution of the role played by Tomo Čačić in establishing Borba in 1931, the first Croatian-language Com- 
By this point, however, such disputes had no wide public resonance. Indeed, Narodni glasnik had by then already ended its days, after a national meeting in Chicago on 18 August 1973 determined to shutter the paper, its readers being encouraged to continue to subscribe to Naše novine. ${ }^{72}$ The final issue of the latter appeared on 16 April 1987. A Toronto group formerly associated with the paper decided to soon thereafter come out with a new publication, Horizont, under the editorship of Josip Gabre, who had previously contributed poems and other literary writing to Jedinstvo. Horizont last appeared in 1991, its demise "conveniently" coinciding with the fall of the Soviet Union and Yugoslavia and marking the end of the "Cominformists" as a group in North America. ${ }^{73}$

\section{Sources and literature}

\section{Archival sources}

Državni arhiv u Rijeci, Edo Jardas.

National Archives of Canada, Ottawa, Rossiiskii tsentr khraneniia i izucheniia dokumentov noveishei istorii, fond 545, opis 6, microfilm reels K-262 and K-263.

Tamiment Institute, New York University, New York, Earl Browder Papers.

\section{Published primary materials}

Kovač, Tatjana (ed.), Glas Splita (1943-1944). Split: Čakavski sabor \& Institut za historiju radničkog pokreta Dalmacije, 1977.

Tito, Josip Broz, Sabrana djela. Belgrade \& Zagreb: Izdavački centar Komunist BIGZ and Naprijed, 1983.

\section{Newspapers}

Borba (Toronto).

Daily Worker (New York).

Fraternal Outlook (Croatian Section) (New York).

Hrvatski svijet (New York).

munist newspaper in Canada. Državni arhiv u Rijeci, Edo Jardas, box 1, folder 4.2 (15 January 1974 letter from Edo Jardas to Marijan Kružić).

72 The last issue of Narodni glasnik appeared on 29 August 1973. Narodni glasnik prestao izlaziti. Naše novine, 5 September 1973, p. 2; and Proglas. Naše novine, 12 September 1973, p. 3.Kostelac, an editor of Naše novine in the 1970s, advised the author that the number of subscribers Naše novine obtained as a result of the folding of Narodni glasnik represented a "trifle" and circulation of the Canadian paper totaled about 2,000 by 1980.

73 Kostelac advised the author that Gabre insisted on continuing to publish Horizont until 1991, to mark $60^{\text {th }}$ anniversary of the Croatian and Yugoslav "labor press" in Canada. Gabre, a native of Šibenik, arrived in Canada in 1959. According to Kostelac, Gabre had fought with the Partisans during World War II. After the war, Yugoslav authorities imprisoned him for 5 years on Goli Otok. Kostelac advises that Gabre died while on a trip to Croatia in 2001. See undated correspondence received in May 2004 from Anton Kostelac to the author; and Rasporich, For a Better Life, p. 217. 
Jedinstvo (Toronto).

Matica (Zagreb).

Narodni glasnik (New York).

Naše novine (Toronto).

Nezavisna Država Hrvatska (Pittsburgh).

The New York Times (New York).

Novi list (New York).

Slobodna misao (Toronto).

Svijet (New York).

\section{Interviews and correspondence}

Anton Kostelac, undated correspondence received by author, May 2004.

Carol Fijan Starobin, interview by author, Great Neck, New York, 26 March 1999.

\section{Monographs}

Adamic, Louis, My Native Land. New York: Harper, 1943.

Adamic, Louis, The Eagle and the Roots. New York: Doubleday \& Company, 1952.

Avakumovic, Ivan, The Communist Party of Canada: A History. Toronto: McClelland and Steward, Ltd., 1975.

Buršić, Herman, Istarska partizanska štampa. Pula: Čakavski sabor, 1981.

Čizmić, Ivan, Jugoslavenski iseljenički pokret u SAD i stvaranje jugoslavenske države 1918. Zagreb: Sveučiliste u Zagrebu - Institut za hrvatsku povijest, 1974.

Čizmić, Ivan, Hrvati u životu Sjedinjenih Američkih Država. Zagreb: Globus, 1982.

Čizmić, Ivan, Povijest Hrvatske bratske zajednice 1894-1994. Zagreb: Golden Marketing, 1994.

Dedijer, Stevan, Stevan Dedijer: Śpijun kojeg smo voljeli. Zagreb: VBZ, 2011.

Dedijer, Vladimir, Dnevnik. Belgrade: Prosveta, 1970, 3rd ed.

20 godina: Kratki pregled naprednog pokreta jugoslavenskib iseljeništva u Kanadi. Toronto: I.O. Vijeća Kanadskih Južnih Slavena, 1950.

Fotich, Constantine, The War We Lost: Yugoslavia's Tragedy and the Failure of the West. New York: The Viking Press, 1948.

Glazer, Nathan, The Social Basis of American Communism. New York: Harcourt, Brace \& World, Inc., 1961.

Govorchin, Gerald, Americans From Yugoslavia. Gainesville, FL: University of Florida Press, 1961.

Haynes, John Earl \& Harvey Klehr, Venona: Decoding Soviet Espionage in America. New Haven, CT: Yale University Press, 1999.

Holjevac, Većeslav, Hrvati izvan Domovine. Zagreb: Matica Hrvatska, 1969.

Isserman, Maurice, Which Side Were You On? The American Communist Party During the Second World War. Urbana, IL: University of Illinois Press, 1993.

Lees, Lorraine M., Yugoslav-Americans and National Security during World War II. Urbana, IL: University of Illinois Press, 2007.

Lojen, Stjepan, Uspomene jednog iseljenika. Zagreb: Znanje, 1963.

Loyen, S. M., Tko gradi, a tko razara H.B.Z. Lijevo krilo u H.B. Zajednici, 1934.

Marković, Mirko, Borba u Americi za novu Jugoslaviju. Belgrade: Prosveta, 1946. 
Marković, Olga B., Doseljenje Srba u Kanadu i njihova aktivnosti. Windsor, Canada: Avala, 1965.

Maštruko, Tomo, Na svim meridijanima. Rijeka: Društvo za proučavanje i unapredjenje pomorstva Jugoslavije, 1975.

Ministry of Foreign Affairs of the Federal People's Republic of Yugoslavia, White Book on Aggressive Activities by the Governments of the USSR, Poland, Czechoslovakia, Hungary, Rumania, Bulgaria and Albania Towards Yugoslavia. Belgrade, 1951.

Mladineo, Ivan, Narodni adresar Hrvata-Slovenaca-Srba. New York: Ivan Mladineo, 1937.

Nelson, Steve, James R. Barett and Rob Ruck, Steve Nelson: American Radical. Pittsburgh: University of Pittsburgh Press, 1981.

Nye, Jr. and Joseph S., Soft Power: The Means To Success In World Politics. New York: Public Affairs, 2004.

Ottanelli, Fraser, The Communist Party of the United States From the Depression to World War II. New Brunswick, NJ: Rutgers University Press, 1991.

Penner, Norman, Canadian Communism: The Stalin Years and Beyond. Toronto: Metheun, 1988.

Prica, Srđa, Amerika (1937-1945). Sarajevo: Oslobodjenje, 1988.

Prpic, George, The Croatian Immigrants in America. New York: Philosophical Library, 1971.

Prpic, George, South Slav Immigrants in America. Boston: Twayne Publishers, 1978.

Rasporich, Anthony W., For a Better Life: A History of the Croatians in Canada. Toronto: McClelland and Stewart, Ltd., 1982.

Rodney, William, Soldiers of the International: A History of the Communist Party of Canada, 19191929. Toronto: University of Toronto Press, 1968.

Skorić, Sofija and George Vid Tomashevich, Serbs in Ontario: A Socio-Cultural Description. Toronto: Serbian Heritage Academy, 1988.

Smoljan, Ivo, Tito $i$ iseljenici - Tito and the Emigrants. Zagreb: Matica iseljenika Hrvatske \& Spektar, 1984.

Smoljan, Ivo, Sto godina Hrvatske bratske zajednice. Zagreb: AGM, 1994.

Stuparić, Darko, Revolucionari i bez funkcija. Rijeka: Otokar Keršovani, 1975.

Suljak, N. Dinko, The Communist Conspiracy in the Croatian Fraternal Union. Arcadia, CA; Croatian Information Series, 1971.

Ujčić, Vincent (ed.), A Journal Commemorating the Opening of the New Modern Restaurant E Bar in the Yugoslav-American Home, 405 West 41 Street, New York. Dec. 19, 1948. New York, 1948.

Vojtěchovsky, Ondřej, Iz Praga protiv Tita! Jugoslavenska informbirovska emigracija u Čehoslovačkoj. Zagreb: Srednja Europa, 2016.

Walker, Thomas J., Pluralistic Fraternity: The History of the International Worker's Order. New York: Garland Publishing, 1991.

Zinn, Howard, Postwar America: 1945-1971. Boston: South End Press, 2002.

\section{Articles}

Čizmić, Ivan, Prilog za istraživanje doprinosa naših iseljenika borbi naroda Jugoslavije u drugom svjetskom ratu. Iseljeništvo naroda i narodnosti Jugoslavije i njegove veze s domovinom. Zagreb: Zavod za migracije i narodnosti, 1978, pp. 71-102.

Granic, Stan, Establishing the South Slavic Radical Labour Press in Canada: The 1931 Reminiscences of Anyox Miner Marko P. Hećimović. Labor vol. 77, 2016, pp. 203-17. 
Hranilović, Nada, Novinarski djelatnost don Nike Grškovića. Časopis za suvremenu povijest vol. 16, 1984, pp. 49-64.

Jonči, Koča, Iseljeništvo - Srbija, SR. Enciklopedija Jugoslavije. Zagreb: Jugoslavenski leksikografski zavod Miroslav Krleža, 1988, vol. 5, pp. 603-08.

Kolar-Dimitrijević, Mira, Odnos KPJ prema jugoslavenskoj radničkoj emigraciji u medjuratnom razdoblju. Časopis za suvremenu povijest vol. 16, 1984, pp. 65-93.

Kraljic, John, The Croatian Section of the Communist Party of the United States and the United Front: 1934-1939. Review of Croatian History vol. 5, 2009, pp. 137-67.

Krišto, Jure, Brother's Keeper: The Surveillance of American Croats by the Federal Bureau of Investigation during World War II. Journal of Croatian Studies vol. 44, 2003, pp. 79-116.

Maletić, Strahinja, Ujedinjeni odbor južno-slovenskih Amerikani. Jugoslovenski napredni pokret u SAD $i$ Kanadi - Progressive Movement of Yugoslavs in the USA and Canada. Toronto: Nordam Jugoslav Publishers, 1983, pp. 71-104.

Novak, Bogdan C., Why Adamic Shifted His Support from Mihailović to Tito. Slovene Studies vol. 11, 1989, pp. 195-92.

Pavlić, Ivanka, Ivan Lindaric, Naši Spanjolski dobrovoljci - I nostri volontari di Spagna - Naši Spanski prosotvoljci. Rijeka: Centar za historiju radničkog pokreta i NOR Istre, Hrvatskog primorja i Gorskog kotara, 1988, pp. 194-98.

Radica, Bogdan, Mi u Americi. Hrvatski kalendar, 1987, pp. 98-103.

\title{
Summary
}

\author{
John P. Kraljic
}

\section{Yugoslav Communities in North America and the Tito-Stalin Split}

World War II had been a watershed in the development of Yugoslav communities in North America. Croatian-Americans and Croatian-Canadians, by far the largest of the three major communities, lived with the shadow of the Independent State of Croatia, which had declared war against, among others, the United States. However, their community's leadership, strongly influenced, alternatively, by Leftist, Communist or Liberal, pro-New Deal ideas, for the most part declared themselves in favor of the Partisans. The leadership of the Serbian community in North America generally favored the restoration of King Peter II and the Chetnik movement. Nevertheless, Serbs in the United States and Canada also had very strong and vocal pro-Communist organizations. The Communist Party of Yugoslavia, which had relied on financial contributions of immigrants in the pre-War years, placed great store on the sympathy of Yugoslav immigrants and followed these developments with sustained interest. The end of the War resulted in these pro-Partisan groups having a preponderant voice in their respective ethnic communities. The Tito-Stalin break in 1948 shattered this outward display of unity. This paper will examine the after effects of the break on the two largest Yugoslav-American communities. Most ethnic Croat and Serb Communists in North America sided with Stalin, ultimately leading to the deterioration of their recently won leadership roles in the communities at large. That some Communists supported Tito gave birth to a vitriolic, decades' long campaign between the 
two competing pro-Communist camps. These disputes caused large internal fractures to arise in and between many organizations, chasms which increased as a result of the growing anti-Communist hysteria in the United States and the influx of large numbers of mainly nationalist, anti-Communist refugees to Canada and the United States from Yugoslavia. These events had profound and damaging effects on the communities and their organizations which continued into the late 1980 s. 